\title{
Türkiye’de Öğrenim Gören Sosyal Bilgiler Öğretmen Adaylarının Hukuk Okuryazarlık Düzeylerinin Belirlenmesi
}

\author{
Hatice KARA \\ Gazi Üniversitesi \\ haticekara@gazi.edu.tr \\ ORCID ID: 0000-0003-1585-0000 \\ Zafer TANGÜLÜ \\ Muğla Sitkı Koçman Üniversitesi \\ zafertangulu@mu.edu.tr \\ ORCID ID: 0000-0003-1596-442X
}

Araştırma Makalesi

DOI: $10.31592 /$ aeusbed.834389

Geliş Tarihi: 01.12.2020

Revize Tarihi: 09.03.2021

Kabul Tarihi: 21.03.2021

\section{Atıf Bilgisi}

Kara, H. ve Tangülü, Z. (2021). Türkiye'de öğrenim gören sosyal bilgiler öğretmen adaylarının hukuk okuryazarlık düzeylerinin belirlenmesi. Ahi Evran Üniversitesi Sosyal Bilimler Enstitüsü Dergisi, 7(1), 341-359.

\section{ÖZ}

Araştırmanın amacı, Türkiye'de öğrenim gören sosyal bilgiler öğretmen adaylarının hukuk okuryazarlık düzeylerini belirlemektir. Araştırma, karma yöntemlerden birisi olan yakınsayan paralel deseni ile oluşturulmuştur. Araştırmanın örneklemini oransız küme örnekleme yolu ile seçilen 2016-2017 Eğitim Öğretim Yılında Sosyal Bilgiler Eğitimi Anabilim Dalı'nda öğrenim gören 610 3. sınıf öğretmen adayı oluşturmaktadır. Araştırmanın nitel boyutunda yer alan çalışma grubu ise amaçlı rastgele örneklem yolu ile belirlenmiştir. Bu bağlamda araştırmada yer alan 12 üniversitenin her birinden bir kadın ve bir erkek olmak üzere toplam 24 sosyal bilgiler öğretmen adayı katılımcı olarak belirlenmiştir. Araştırmada nicel veri toplama aracı olarak, araştırmacı tarafından geliştirilen hukuk okuryazarlık ölçeği ve hukuk okuryazarlık bilgi testi kullanılmıştır. Nitel veri toplama aracı olarak ise araştırmacı tarafından geliştirilen yarı yapılandırılmış görüşme formu kullanılmıştır. Araştırmada, sosyal bilgiler öğretmen adaylarının hukuk okuryazarlık bilgi, tutum ve davranış düzeylerinin orta düzeyde yer aldığı; hukuk okuryazarlık bilgi düzeylerinin erkek öğretmen adaylarının lehine anlamlı bir fark gösterdiği; hukuki süreç yaşamış olma değişkenine göre hukuki süreç yaşayan öğretmen adaylarının hukuk okuryazarlık bilgi, tutum ve davranışlarının daha yüksek düzeyde olduğu; öğretmen adaylarının birçoğunun sosyal bilgiler dersi kapsamında hukuk konularının öğretiminde kendilerini yeterli görmedikleri ve hukuk öğrenimini uygulamaya dayalı ve sosyal yaşam ile birleştirilmiş olarak almak istedikleri sonuçlarına ulaşılmıştır.

Anahtar Kelimeler: Hukuk okuryazarlığı, sosyal bilgiler öğretmen adayları, etkin vatandaş yetiştirme.

\section{Determination of Legal Literacy Levels of Social Studies Teacher Candidates Studying in Turkey}

\begin{abstract}
The purpose of this study is to determine the level of legal literacy, social studies teacher candidates studying in Turkey. The research was created with a convergent parallel pattern, which is one of the mixed methods. The sample of the study consists of 610 3rd grade teacher candidates studying in the Department of Social Studies Education in the 2016-2017 Academic Year, which were selected by disproportionate cluster sampling. The study group in the qualitative dimension of the study was determined by purposeful random sampling. In this context, a total of 24 social studies teacher candidates, one female and one male from each of the 12 universities included in the study, were determined as participants. The legal literacy scale and legal literacy knowledge test developed by the researcher were used as quantitative data collection tools in the study. The semi-structured interview form developed by the researcher was used as a qualitative data collection tool. The result of the study are presented as follow; the level of knowledge, attitude and behavior of legal literacy of social studies teacher candidates is moderate; The level of legal literacy showed a significant difference in favor of male teacher candidates; The legal literacy knowledge, attitudes and behaviors of the teacher candidates who have experienced a legal process are higher according to the variable of having a legal process; Many of the prospective teachers have come to the conclusion that they want to take legal education as an implementation based on social studies and they think they are inadequate in the teaching of legal subjects within the scope of social studies course.
\end{abstract}

Keywords: Legal literacy, prospective social studies teachers, effective citizen education. 


\section{Giriş}

Demokrasiyi benimsemiş devletlerde hukuk, devletin yönetim biçiminden ayrı düşünülemez. Çünkü toplum içerisinde yer alan bireyin ya da sosyal grupların korunması, elde edilen hakların yerine getirilmesi için mücadele edilmesi ve siyasi karar alma süreçlerine katılımının sağlanması ancak hukuk kurallarının uygulanması ile mümkün olabilir (Skopska, 2001). Bu bağlamda demokrasi rejimi ile yönetilen her devlet, hukukun varlığına ihtiyaç duyduğu kadar hukukun belirli bir düzen içerisinde sürmesini sağlayan etkin bireylere de ihtiyaç duymaktadır (Aydın, 2015). Çünkü demokrasi bir siyasal yönetim biçimi olmanın yanı sıra aynı zamanda bir yaşam şeklidir (Bakır, 2014).

Hukuk okuryazarlığı, bireylerin kendi haklarının ve kişisel özgürlüklerinin farkında, haysiyet ve özgürlük içinde yaşayabildiği, toplumsal korkulardan uzak, bireysel yaşamın kapsam ve boyut olarak en geniş biçimde yaşandığı toplumlar için büyük bir gereklilik arz etmektedir (Braye ve Preston Shoot, 2005; Upadhyay, 2005). Hukuk okuryazarlığı terimi ile ilgili literatürde birçok farklı tanım yapılmıştır. Manley Casimir, Cassidy ve Castell'e (1986) göre hukuk okuryazarlı̆̆ 1 terimi, temel bir hukuki yeterliliğin ötesinde; hukukun özü, yasal süreç ve yasal kaynaklar hakkında bilgi, anlayış ve eleştirel yargılama anlamına gelmektedir. American Bar Association (1989) hukuk okuryazarlık terimini yasanın özünü, yasal süreci ve mevcut yasal kaynaklar hakkında eleştirel değerlendirmeler yapma ve hukuk sistemini etkin bir şekilde kullanarak yasal sistemi iyileştirme stratejilerini ifade etme becerisi olarak tanımlamıştır. Canada Bar Association [CBA] (1992) ise hukuk okuryazarlık terimini hukuki bir bağlamda kullanılan sözcükleri anlama, bu sözcüklerden sonuç çıkarma ve çıkardığı sonuçlar doğrultusunda harekete geçme becerisi olarak tanımlamıştır. Bu tanımlara ek olarak Hasan (1994) hukuk okuryazarlık terimini, bireylerin yalnızca sahip oldukları hakları etkinleştirmekle kalmayıp, hukuk ve uygulamada ifade edilen yetersizlikleri yeniden tanımlamak ve yeniden şekillendirmek için harekete geçiren bir benlik ve sosyal güçlenme süreci olarak ele almıştır. Modern anlamda hukuk okuryazarlık kavramının gelişimi vatandaşları hukuk uzmanları kadar toplum içerisinde etkin bir hale getirmeyi hedeflemektedir. Diğer bir deyişle hukuk okuryazarlığ demokraside etkin olarak görev alabilme yeteneğini içermektedir. Bu bakımdan hukuk okuryazarlığı etik, profesyonel, kişisel ve bilişsel yapıların yanı sıra duygusal ve örgütsel yapıların da ihtiyaçlarına cevap verebilmek için gereklidir (Bilder, 1999; Braye ve Shoot, 2005; Doran ve Hoffman, 2005; Fultz, 2015; Korpiola, 2015; Snook, Lurher, Eastwood, Collins ve Evans,2014; Steininger ve Rückel, 2013; Zariski, 2014). Yasal bir toplumun anlamlı kilınabilmesi için toplumda yer alan bireylerin birer hukuk okuryazarı olması gerekmektedir. Başka bir ifadeyle hukuk okuryazarlığı, toplumdaki tüm bireyleri kapsamaktadır (Bell ve Pether, 1998). Devletin bu noktadaki en önemli görevi ise hak ve sorumluluklarının farkında olan bireyler yetiştirmek ve bu bireylerin yetişecekleri ortamın şartlarını sağlamaktır (Çuhadar ve Doğanay, 2014).

Demokrasi açısından eğitimin temel amaçlarından biri, bireyleri insan hak ve özgürlüklerinin farkında, demokratik değer ve tutumu içselleştirmiş ve onları davranışa dönüştüren etkin vatandaşlar haline getirebilmektir (Milli Eğitim Bakanlığı [MEB], 2009a). Bu nedenle 1970'lilerin başından itibaren ilkokul ve ortaokul düzeyindeki öğrencilerin sosyal bilgiler dersi müfredatına hukuk ile ilgili konular eklenmeye başlanmıştır (Naylor, 1976; Öztürk, 2009). Eklenen konular genel olarak temel hukuki kavramlar, suç ve ceza yasası, anayasa, medeni kanun ve insan hakları beyannamesi gibi öğrencilerin düzeylerine uygun olacak şekilde belirlenmiştir (Merey, Karatekin ve Kuş, 2012). Sosyal bilgiler dersinde yer alan bu konular hukuk çalışmalarında uzmanlaşmaya değil, bir vatandaş olarak demokrasi ile hukuk arasındaki ilişkiyi anlamlandırmaya odaklanır (Leming, 1995). Bu bağlamda hukuk çalışmaları öğrencilere içinde bulundukları toplumsal yapı ve toplumsal değerleri öğretmek amacıyla bir araç olarak kullanılır (Naylor, 1976).

Bireyin toplumsal yaşama adapte olmasını amaçlayan sosyal bilgiler dersi; insan hakları, demokrasi ve vatandaşlık konularının öğretiminde hukuk ile ilgili kavram ve bilgilerden yararlanmaya gereksinim duyar (Yazıcı ve Erdilmen, 2015). Sosyal bilgiler dersi içerisinde yer alan hukuk konularının öğretimi, öğrencilerin hukuki bilgi, beceri ve tutumlarını geliştirmenin yanı sıra etkin vatandaşlık için gerekli olan hukuki rolleri de geliştirmeye olanak sağlar (Leming, 1995). Bu bağlamda sosyal bilgiler öğretmenlerinin vatandaşlık eğitimi konusunda önemli görev ve 
sorumlulukları vardır. Bu görev ve sorumlulukları yerine getirebilmek için ise vatandaşlık eğitimini oluşturan tüm konulara hâkim olmaları, etkin vatandaşlık için gerekli olan becerilere sahip olmaları ve vatandaşlık eğitimini oluşturan etmenlere karşı olumlu tutum sergilemeleri beklenmektedir (National Council for the Social Studies [NCSS], 1994). Geleceğin etkin vatandaşlarını yetiştirecek olan sosyal bilgiler öğretmen adaylarının etkili bir öğretim gerçekleştirebilmeleri için ise iyi birer hukuk okuryazarı olması büyük önem taşımaktadır. Bu bağlamda araştırmada sosyal bilgiler dersi kapsamında hukuk konularını öğretecek olan sosyal bilgiler öğretmen adaylarının hukuk okuryazarlık düzeylerini belirlemekle birliktesosyal bilgiler dersi kapsamında hukuk ve hukuk öğretimine yönelik düşüncelerini incelemek amaçlanmıştır.

\section{Yöntem}

\section{Araștırma Modeli/Deseni}

Araştırmada karma araştırma yöntemlerinden birisi olan yakınsayan paralel desen modeli kullanılmıştır. Karma yöntem ile oluşturulan araştırmalar, araştırmanın genişliği ve derinliğini belirlemek amaciyla nicel ve nitel yöntemlerin birleştirilmesi sonucu oluşur (Robson, 2015). Yakınsayan paralel desen modelinde, kullanılan her iki yönteme eşit düzeyde öncelik verilir. Analiz sırasında yöntemlerin aşamaları birbirinden ayrı tutulurken, yorumlama aşamasında sonuçlar birleştirilir. Bu araştırma deseni, araştırmacının nicel ve nitel aşamaları araştırma süreci içerisinde aynı zamanda uygulamasıyla oluşur. Böylece araştırmacı, araştırmada kullanılan nicel yöntem ile nitel yöntemin güçlü ve birbiri ile uyuşmayan zayıf yönlerini bir araya getirerek araştırma konusunun daha etkili bir şekilde anlaşılmasını sağlar (Creswell ve Clark, 2015).

\section{Çalışma Grubu/Evren ve Örneklem}

Araştırmanın örneklemini oransız küme örnekleme yolu ile seçilen 2016-2017 Eğitim Öğretim Yılı'nda Sosyal Bilgiler Eğitimi Anabilim Dalı'nda öğrenim gören 610 3. sınıf öğretmen adayları oluşturmaktadır. Oransız küme örnekleme yolu ile seçilen örneklemin belirlenmesinde, Türkiye İstatistik Kurumu [TÜIK] verilerinden elde edilen istatistiki bölge birimleri sinıflaması temel alınmıştır. Üçüncü sınıf sosyal bilgiler öğretmen adaylarının örneklem olarak seçilmesinin en önemli nedeni ise 1. ve 2. sinıfta hukuk okuryazarlığına yönelik "İnsan Hakları ve Demokrasi", "Temel Hukuk" ve "Vatandaşlık Bilgisi" gibi temel dersleri almış olmalarıdır. Araştırmaya katılan örneklem grubunun cinsiyete ve okuduğu bölgeye ilişkin bilgileri Tablo 1 ve Tablo 2'de sunulmuştur.

Tablo 1

Örneklemin Cinsiyet Dă̆ılımına İlişkin Frekans ve Yüzde Değerleri

\begin{tabular}{lll}
\hline Cinsiyet & N & $\%$ \\
\hline Kadın & 360 & 59,0 \\
Erkek & 250 & 41,0 \\
Toplam & 610 & 100 \\
\hline
\end{tabular}

Tablo 2

Örneklemin Öğrenim Gördüğ̈̈ Bölgeye İlişkin Frekans ve Yüzdelik Dă̆gllm Değerleri

\begin{tabular}{lll}
\hline Öğrenim Gördü̆̆̈̈ Bölge & $\mathbf{N}$ & $\mathbf{\%}$ \\
\hline İstanbul & 45 & 7,4 \\
Batı Marmara & 51 & 8,4 \\
Ege & 60 & 9,8 \\
Doğu Marmara & 43 & 7,0 \\
Batı Anadolu & 45 & 7,4 \\
Akdeniz & 43 & 7,0 \\
Orta Anadolu & 41 & 6,7 \\
Güneydoğu Anadolu & 51 & 8,4 \\
\hline
\end{tabular}




\begin{tabular}{lll}
\hline Batı Karadeniz & 42 & 6,9 \\
Doğu Karadeniz & 72 & 11,8 \\
Kuzeydoğu Anadolu & 58 & 9,5 \\
Ortadoğu Anadolu & 59 & 9,7 \\
Toplam & 610 & 100 \\
\hline
\end{tabular}

Araştırmanın nitel boyutunda ise çalışma grubu amaçlı rastgele örneklem yolu ile belirlenmiştir. Bu örnekleme türü, var olan durumların ortaya çıkarılmasında seçilen çalışma grubunun niçin araştırma için seçildiğine dair var olan şüpheleri azaltarak güvenilirliği arttırmaya yönelik olarak kullanılır (Patton, 2014). Bu bağlamda araştırmada yer alan 12 üniversitenin her birinden bir kadın ve bir erkek olmak üzere, gönüllülük esasına dayalı olarak toplam 24 sosyal bilgiler öğretmen adayı katılımcı olarak belirlenmiştir.

\section{Veri Toplama Araçları}

Araştırmada nicel verileri toplamak için araştırmacı tarafından geliştirilen Hukuk Okuryazarlık Bilgi Testi ile Hukuk Okuryazarlık Ölçeği; nitel verileri toplamak için ise araştırmacı tarafından geliştirilen yarı yapılandırılmış görüşme formu kullanılmıştır.

\section{Hukuk Okuryazarlık Bilgi Testi}

Araştırmacı tarafından geliştirilen bu ölçme aracı katılımcıların temel hukuk konularına yönelik bilgi düzeylerini belirlemek amacı ile kullanılmıştır. Ölçme aracının kapsam geçerliliğinin sağlanması için sosyal bilgiler eğitiminde doktoralı üç araştırmacı, hukuk alanında uzman iki araştırmacı,ölçme ve değerlendirme alanında doktoralı bir araştırmacının uzman görüşlerine başvurulmuştur. Uzman görüşleri doğrultusunda 4 madde çıkarılmış ve 3 madde ölçme aracına eklenmiştir. Son hali ile hukuk okuryazarlık bilgi testi dört öncüllü 26 maddeden oluşmuş ve KR-20 güvenilirlik katsayısı 0.74 olarak hesaplanmıştır. Eğitim ve öğretimde yer alan amaçları gerçekleştirmedeki başarı ve bilgi düzeylerini belirlemek için kullanılan testlerdeki KR-20 güvenilirlik katsayısının, 0.70 ve üzerinde olması testin güvenilir olduğunu göstermektedir (Büyüköztürk, 2007; Şeker ve Gençdoğan, 2014). Bu bağlamda hukuk okuryazarlık bilgi testinin güvenilirliğinin yeterli düzeyde olduğu söylenebilir. Literatür incelendiğinde ise hukuk okuryazarlık bilgi testinin, Oğuz'un (2013) hukuk okuryazarlığını ölçen ölçme aracı ile paralellik gösterdiği göze çarpmaktadır.

\section{Hukuk Okuryazarlık Ölçeği}

Öğretmen adaylarının hukuk okuryazarlık düzeylerini ölçmek amacıyla geliştirilen hukuk okuryazarlık ölçeği 5'li likert tipinde ve 29 maddeden oluşmaktadır. İlgili ölçek "hukuka güven", "hukuka ilgi”, "hukuki sorumluluk", "hukuki yaptırım", "günlük hayat ile ilişkilendirme", "hukuku kullanma" ve "kuralsızlık" olmak üzere 7 alt boyuttan oluşmaktadır. Ölçek geliştirme aşamasında sırasıyla açımlayıcı ve doğrulayıcı faktör analizleri uygulanmış ve ölçeğe son şekli verilmiştir. Ölçeğinin toplam cronbach's alpha güvenilirlik katsayısı ,81 olduğu görülmüştür. Ölçeğin toplam cronbach's alpha değerinin ,60 ile ,90 arasında olması, ölçeğin oldukça güvenilir olduğunu göstermektedir (Can, 2014).

\section{Yarı Yapılandırılmış Görüşme Formu}

Sosyal bilgiler öğretmen adaylarının sosyal bilgiler dersi kapsamında hukuk ve hukuk öğretimi arasındaki bağı derinlemesine incelemek amacıyla, nitel veri toplama araçlarından biri olan yarı yapılandırılmış görüşme formu kullanılmıştır. Araştırmada kullanılan veri toplama aracı araştırmacı tarafından geliştirilmiştir. Oluşturulan veri toplama aracı, biri hukuk, ikisi sosyal bilgiler eğitimi ve biri Türkçe olmak üzere alanında uzman toplam dört araştırmacı tarafindan değerlendirilmiştir. Yapılan değerlendirme sonucu beş sorudan oluşan yarı yapılandırılmış görüşme formundan iki soru çıkarılmış ve ön uygulama gerçekleştirilmiştir. Dört sosyal bilgiler öğretmen 
adayıyla gerçekleştirilen ön uygulama sonucunda bir soru revize edilerek, veri toplama aracına son şekli verilmiştir. Ölçme aracında yer alan sorular, sosyal bilgiler dersi ve hukuk arasındaki bağlantının yordanması; öğretmen adaylarının sosyal bilgiler öğretim programı içerisinde yer alan hukuk konularını öğretebilme konusunda kendilerini ne kadar yeterli gördüklerine dair görüşleri ve nasıl bir hukuk öğrenimi almak istediklerine yönelik konularını kapsamaktadır.

\section{Verilerin Toplanması ve Analizi}

Nicel verilerin analizinde SPSS.21 analiz programından yararlanılmıştır. Hukuk okuryazarlık bilgi testi için 3 uzmanın görüşüne başvurularak bilgi testinden alınan puanlar düşük, orta ve yüksek olmak üzere üç düzeye ayrılarak analiz edilmiştir. Tüm sorulara doğru cevap verildiği takdirde alınacak puan 100, tüm sorulara yanlış cevap verildiği takdirde alınacak puan 0'dır. Katılımcı puanları bu skalaya göre düzenlenmiştir. Hukuk okuryazarlık bilgi testinin verileri betimsel ve çıkarımsal analizlere tabi tutulmuştur. Hukuk okuryazarlık bilgi testi için analize başlamadan önce veri setinin normallik varsayımını sağlayıp sağlamadığını Kolmogorov-Simirnov testi ile incelenmiştir. Kolomogorov-Simirnov testi sonucu p değerinin 0,05 'in altında kaldığ 1 araştırmalarda veri setinin normallik varsayımını karşılamadığı varsayılmaktadır (Field, 2009). Yapılan analiz sonucu p değerinin 0,05 'in altında olduğu görülmüş ve veriler nonparametrik testler olan Mann-Whitney $U$ testi ve Kruskal-Wallis Varyans testi ile analiz edilmiştir.

5'li likert tipte hazırlanan ve toplam 29 maddeden oluşan hukuk okuryazarlık ölçeğinden ise alınabilecek en düşük puan 29 , en yüksek puan ise $145^{\prime}$ tir. Beş uzmanın görüşüne başvurulduktan sonra ölçek; çok düşük, düşük, orta, yüksek ve çok yüksek olmak üzere beş düzeye ayrılmıştır. Hukuk okuryazarlık ölçeğinin verileri betimsel ve çıkarımsal analiz yöntemlerine tabi tutulmuştur. Elde edilen veriler analiz edilmeden önce verilerin normallik varsayımını karşılayıp karşılamadığı test edilmiştir. Kolomogorov-Simirnov testi sonucu p değerinin 0,05'in altında kaldığ 1 araştırmalarda veri setinin normallik varsayımını karşılamadığı varsayılmaktadır (Field, 2009). Analiz sonucunda KolmogorovSimirnov testi $\mathrm{p}$ değerinin 0,05 'in altında olduğu görülmüş ve veri seti, nonparametrik testler olan Mann-Whitney U testi ve Kruskal-Wallis Varyans testi ile analiz edilmiştir.

Birebir görüşmeler sonucu elde edilen nitel veriler içerik analizi kullanılarak çözümlenmiştir. Araştırmada içerik analizi kullanılmasının amacı, elde edilen verilere ilişkin kavramları ve bu kavramlar arasındaki ilişkiyi açıklamaktır (Yıldırım ve Şimşek, 2008). Verilerin kaybını önlemek amacıyla görüşmeler esnasında katılımcıların rızasıyla araştırmacı tarafından ses kayıt cihazı kullanılmıştır. Görüşmelerin sonunda bilgisayar ortamına aktarılan veriler, araştırmacı tarafından transkript edilmiştir. Analiz sürecinde veriler ilk önce serbest kodlarla oluşturulmuş daha sonra özelliklerine göre temalar haline dönüş̧ürülmüştür. Araştırmanın güvenilirliğini arttırmak amacıyla elde edilen bulgular iki ayrı araştırmacı tarafından değerlendirilerek, kodlar ve temalar puanlamaya tabi tutulmuştur. Ayrı ayrı oluşturulan bu kodların uyum yüzdesine bakılmıştır. Uyum yüzdesini hesaplamada Miles ve Huberman (1994) tarafindan belirtilen $\mathrm{P}=(\mathrm{Nax} 100)(\mathrm{Na}+\mathrm{Nd})(\mathrm{P}$ : uyum yüzdesi, Na: uyum miktarı, Nd: uyuşmazlık miktarı) eşitliği kullanılmıştır. Araştırmacılar tarafından hesaplanan uyum yüzdesi \% 84.4 olarak bulunmuştur. Yıldırım ve Şimşek (2008) tarafından yapılan güvenirlik hesaplamasında uyum yüzdesinin $\% 70$ ve üzeri olması, araştırmanın güvenirlik yüzdesini sağlamış olduğunu gösterir. Verilerin analizinde katılımcı kontrolü de sağlanarak araştırmanın güvenilirliği arttırılmıştır.

\section{Araştırma Süreci ve Etiği}

Sosyal bilgiler öğretmen adaylarının hukuk okuryazarlık düzeylerinin belirlenmesini amaçlayan araştırmada, belirlenen 12 bölgede yer alan toplam 12 üniversiteden veriler toplanmıştır. Uygulama süreci öncesinde belirlenen üniversitelerden uygulama izinleri alınmıştır. Veri toplama sürecinde uygulamalar araştırmacı tarafından gerçekleştirilmiştir. Araştırma verilerinin toplanması 2016-2017 Eğitim Öğretim Yılı Bahar ve Güz yarıyıllarını kapsayacak şekilde üç aşamada gerçekleşmiştir. Veri toplama sürecinin ilk aşaması 28.11.2016 ile 09.12.2016 tarihleri arasında, sirasıyla Doğu Karadeniz, Kuzeydoğu Anadolu, Ortadoğu Anadolu, Güneydoğu Anadolu ve Akdeniz 
bölgelerini kapsamaktadır. İkinci aşaması 20.02.2017 tarihinde Ege bölgesinde gerçekleştirilmiştir. Üçüncü ve son aşama ise 27.02.2017 ile 10.03.2017 tarihleri arasında, sırasıyla Batı Marmara, İstanbul, Batı Karadeniz, Orta Anadolu, Doğu Marmara ve Batı Anadolu bölgelerini kapsamaktadır. Araştırmada nicel ve nitel veriler eş zamanlı toplanmıştır. Araştırmanın nitel veri toplama sürecinde gönüllük esasına göre belirlenmiş katılımcılar ile birebir görüşmeler katılımcıların kendilerini rahat hissedebileceği bir ortamda gerçekleştirilmiştir. Öğretmen adaylarıyla gerçekleştirilen birebir görüşmeler en az 12, en fazla ise 35 dakika sürmüştür. Araştırmanın etiği gereği çalışmanın uygun bulunduğuna dair etik kurul onayı Muğla Sitkı Koçman Üniversitesi'den; uygulanabileceğine dair etik onay yazıları ise uygulama yapılan üniversitelerden alınmıştır. Ayrıca katılımcıların adlarına çalışmanın hiçbir yerinde yer verilmemiş; katılımcılar K1,K2, K3,.. gibi simgelerle kodlanmıştır.

\section{Bulgular}

Sosyal Bilgiler öğretmen adaylarının hukuk okuryazarlık bilgi düzeylerini incelemek amacıyla hukuk okuryazarlık bilgi testi kullanılmıştır. Öğretmen adaylarının bilgi testinden alabilecekleri en yüksek puan 100, en düşük puan ise 0'dır. Bilgi testi "0- 33,3" arası düşük, "33,4-66,6" arası orta ve "66,7-100" arası yüksek olmak üzere üç düzeye ayrılmıştır. Sosyal bilgiler öğretmen adaylarının hukuk okuryazarlık bilgi testine ilişkin aritmetik ortalama ve standart sapma değerleri Tablo 3'te sunulmuştur.

Tablo 3

Sosyal Bilgiler Öğretmen Adaylarının Hukuk Okuryazarlık Bilgi Düzeylerine İlişkin Aritmetik Ortalama ve Standart Sapma Değerleri

\begin{tabular}{llll}
\hline Bilgi Düzeyi & $\mathbf{N}$ & $\mathbf{X}$ & Ss \\
\hline$f$ & 610 & 55,06 & 14,66 \\
\hline
\end{tabular}

Tablo 3 incelendiğinde öğretmen adaylarının hukuk okuryazarlık bilgi testinden aldıkları aritmetik puanın ortalamas $\mathrm{X}=55,06$, standart sapmanın ise $\mathrm{Ss}=14,66$ olduğu görülmektedir. Elde edilen bu değerlere göre, sosyal bilgiler öğretmen adaylarının hukuk okuryazarlık bilgi düzeylerinin çoğunlukla orta düzeyde olduğu söylenebilir.

Sosyal bilgiler öğretmen adaylarının hukuk okuryazarlık bilgi testinden aldıkları puanlar cinsiyet ve hukuki süreç yaşama değişkenlerine göre incelenmiştir. Öğretmen adaylarının belirlenen değişkenlere göre bilgi testinden aldıkları puanları analiz etmeden önce, veri setinin normallik varsayımını sağlayıp sağlamadığını test etmek amacıyla Kolmogorov-Simirnov ve Shapiro-Wilk testi yapılmış, analiz sonucuna ait bulgular Tablo 4' de sunulmuştur.

Tablo 4

Hukuk Okuryazarlık Bilgi Testinden Elde Edilen Verilere İlişkin Normallik Değerleri

\begin{tabular}{lllllll} 
& \multicolumn{5}{c}{ Kolmogorov-Simirnov } & \multicolumn{2}{c}{ Shapiro-Wilk } \\
& İstatistik & Ss & p & İstatistik & Ss & p \\
\hline Toplam &, 094 & 610 &, 000 &, 976 & 610 &, 000 \\
\hline
\end{tabular}

Tablo 4 incelendiğinde veri setinin Kolmogorov-Simirnov ve Shapiro-Wilk testlerine göre normallik varsayımını karşılamadığı görülmektedir $(\mathrm{p}<0,05)$. Bu bağlamda çıkarımsal analizler, nonparametrik testler olan Mann Whitney U ve Kruskal-Wallis testleri ile gerçekleştirilmiştir.

Tablo 5

Sosyal Bilgiler Öğretmen Adaylarının Hukuk Okuryazarlık Bilgi Puanlarının Cinsiyet Değişkenine Göre Mann Whitney U Testi Sonuçları

\begin{tabular}{llllll}
\hline Cinsiyet & $\mathbf{N}$ & Sira Ortalaması & Sira Toplamı & U & p \\
\hline Kadın & 360 & 278,27 & 100176,56 & & \\
Erkek & 250 & 344,71 & 86178,50 & 35196,5 &, 000 \\
\hline
\end{tabular}


Tablo 5 incelendiğinde sosyal bilgiler öğretmen adaylarının hukuk okuryazarlık bilgi puanlarının cinsiyet değişkenine göre, erkek öğretmen adaylarının lehine anlamlı bir fark gösterdiği anlaşılmaktadır $(\mathrm{U}=35196,5, \mathrm{p}<0,05)$. Bu bulgudan yola çıkarak, cinsiyet değişkenin hukuk okuryazarlık bilgisine anlamlı bir etkisinin olduğu söylenebilir.

Tablo 6

Sosyal Bilgiler Öğretmen Adaylarının Hukuk Okuryazarlık Bilgi Testi Puanlarının Hukuki Süreç Yaşamış Olma Değişkenine Göre Mann Whitney U Testi Sonuçları

\begin{tabular}{llllll}
\hline $\begin{array}{l}\text { Hukuki Süreç } \\
\text { Yaşamış Olma }\end{array}$ & N & Sıra Ortalaması & Sıra Toplamı & U & p \\
\hline Hayır & 542 & 284,73 & 154324,0 & & \\
Evet & 68 & 471,04 & 32031,0 & 7171,0 &, 000 \\
\hline
\end{tabular}

Tablo 6 incelendiğinde, sosyal bilgiler öğretmen adaylarının hukuk okuryazarlık bilgi puanlarının hukuki süreç yaşamış olma değişkenine göre, hukuki süreç yaşamış olan öğretmen adaylarının lehine anlamlı bir fark gösterdiği anlaşılmaktadır $(\mathrm{U}=7171,0, \mathrm{p}<0,05)$. Bu bulgudan yola çıkarak, daha önce hukuki bir süreç yaşamış olma değişkeninin hukuk okuryazarlık bilgisi üzerinde anlamlı bir etkisinin olduğu söylenebilir.

Sosyal bilgiler öğretmen adaylarının hukuk okuryazarlık düzeylerinin belirlenmesine ilişkin geliştirilen bir diğer ölçme aracı ise hukuk okuryazarlık ölçeğidir. Öğretmen adaylarının ölçme aracından alabilecekleri en düşük puan 29 , en yüksek puan ise 145 'tir. Hukuk okuryazarlık ölçeği 3 uzmanın görüşüne başvurulduktan sonra "29-52,2" aras1 çok düşük, "52,3-75,4" aras1 düşük, "75,598,6" arası orta, "98,7-121,8” arası yüksek ve "121,9-145” arası çok yüksek olmak üzere beş düzeye ayrılmıştır. Sosyal Bilgiler öğretmen adaylarının hukuk okuryazarlık ölçeğinden aldıkları puanların aritmetik ortalama ve standart sapma değerleri Tablo 7'de sunulmuştur.

Tablo 7

Sosyal Bilgiler Öğretmen Adaylarının Hukuk Okuryazarlık Ölçeğinden Aldıkları Puanların Aritmetik Ortalama ve Standart Sapma Değerleri

\begin{tabular}{lllllll}
\hline & & N & En Düşük Puan & En Yüksek Puan & X & \multicolumn{2}{l}{ Ss } \\
\cline { 2 - 7 } $\begin{array}{l}\text { Hukuk } \\
\text { Okuryazarlık }\end{array}$ & $f$ & 610 & & & & \\
Ölçeği & $\%$ & 100 & 45,0 & 123,0 & 95,45 & 11,64 \\
\hline
\end{tabular}

Tablo 7 incelendiğinde sosyal bilgiler öğretmen adaylarının hukuk okuryazarlık ölçeğinden aldıkları puanların aritmetik ortalaması $(X=95,45)$, standart sapmasının ise $(\mathrm{sd}=11,64)$ olduğu görülmektedir. Bu bulgudan yola çıkarak öğretmen adaylarının hukuk okuryazarlık ölçeğine göre okuryazarlık düzeylerinin çoğunlukla orta düzeyde yer aldığı söylenebilir.

Sosyal ilgiler öğretmen adaylarının hukuk okuryazarlık ölçeğinden aldıkları puanlar cinsiyet ve hukuki süreç yaşama değişkenlerine göre incelenmiştir. Öğretmen adaylarının belirlenen değişkenlere göre hukuk okuryazarlık ölçeğinden aldıkları puanları analiz etmeden önce, veri setinin normallik varsayımını sağlayıp sağlamadığını test etmek amacıyla Kolmogorov-Simirnov ve ShapiroWilk testi yapılmış, analiz sonucuna ait bulgular Tablo 8'de sunulmuştur.

Tablo 8

Hukuk Okuryazarlık Ölçeğinden Elde Edilen Verilere İlişkin Normallik Değerleri

\begin{tabular}{|c|c|c|c|c|c|c|}
\hline & \multicolumn{3}{|c|}{ Kolmogorov-Simirnov } & \multicolumn{3}{|c|}{ Shapiro-Wilk } \\
\hline & İstatistik & Ss & $\mathbf{p}$ & İstatistik & Ss & $\mathbf{p}$ \\
\hline Toplam & 057 & 610 &, 000 & ,975 & 610 &, 000 \\
\hline
\end{tabular}


Tablo 8 incelendiğinde veri setinin Kolmogorov-Simirnov ve Shapiro-Wilk testlerine göre normallik varsayımını karşılamadığı görülmektedir $(\mathrm{p}<0,05)$. Bu bağlamda çıkarımsal analizler, nonparametrik testler olan Mann Whitney U ve Kruskal-Wallis testleri ile gerçekleştirilmiştir.

Tablo 9

Sosyal Bilgiler Öğretmen Adaylarının Hukuk Okuryazarlık Ölçeği Puanlarının Cinsiyet Değişkenine Göre Mann Whitney U Testi Sonuçları

\begin{tabular}{llllll}
\hline Cinsiyet & N & Sira Ortalaması & Sira Toplamı & U & p \\
\hline Kadın & 360 & 302,09 & 108754,0 & & \\
Erkek & 250 & 310,40 & 77601,0 & 4377,0 &, 567 \\
\hline
\end{tabular}

Tablo 9 incelendiğinde, sosyal bilgiler öğretmen adaylarının hukuk okuryazarlık ölçeği puanlarının cinsiyet değişkenine göre anlamlı bir fark göstermediği gözlenmektedir (U=4377,0, $\mathrm{p}>0,05)$.

Tablo 10

Sosyal Bilgiler Öğretmen Adaylarının Hukuk Okuryazarlık Ölçeği Puanlarının Hukuki Süreç Yaşamış Olma Değişkenine Göre Mann Whitney U Testi Sonuçları

\begin{tabular}{llllll}
\hline $\begin{array}{l}\text { Hukuki Süreç } \\
\text { Yaşamış Olma }\end{array}$ & N & Sıra Ortalaması & Sıra Toplamı & U & p \\
\hline Hayır & 542 & 296,88 & 160908,0 & & \\
Evet & 68 & 374,22 & 25447,0 & 13755,0 &, 001 \\
\hline
\end{tabular}

Sosyal bilgiler öğretmen adaylarının hukuk okuryazarlık ölçeği puanları hukuki süreç yaşamış olma değişkenine göre incelendiğinde, hukuki süreç yaşamış olan öğretmen adaylarının lehine anlamlı bir fark olduğu görülmektedir $(\mathrm{U}=13755,0, \mathrm{p}<0,05)$. Bu bulgudan yola çıkarak, hukuki bir süreç yaşamış olma değişkeninin hukuk okuryazarlık düzeyi üzerinde anlamlı bir etkisinin olduğu söylenebilir.

Sosyal bilgiler öğretmen adaylarının sosyal bilgiler dersi kapsamında, hukuk ve hukuk öğrenimine yönelik düşüncelerinin belirlenmesi amacıyla ise yarı yapılandırılmış görüşme formu kullanılmıştır.

Tablo 11

Sosyal Bilgiler Öğretmen Adaylarının Sosyal Bilgiler Dersi ve Hukuk Arasındaki İlişkiye Dair Görüşleri

\begin{tabular}{|c|c|c|c|c|}
\hline Tema & Alt Tema & Kodlar & $f$ & Katılımeı \\
\hline & \multirow{6}{*}{$\begin{array}{l}\text { Kapsam } \\
\text { Boyutu }\end{array}$} & Tarih-Hukuk İlişkisi & 1 & K1 \\
\hline & & Sosyal Bilim & 3 & $\mathrm{~K} 3, \mathrm{~K} 4, \mathrm{~K} 9$ \\
\hline & & Günlük Hayat Birlikteliği & 7 & $\begin{array}{l}\text { K2, K8, K11, K14, } \\
\text { K19, K21, K4 }\end{array}$ \\
\hline & & Hukuk- Coğrafya İlişkisi & 1 & K6 \\
\hline & & Toplumsal Değer & 1 & K20 \\
\hline & & $\begin{array}{l}\text { Sosyal Bilgiler Dersinin } \\
\text { Disiplinleraras1 Yapıs1 }\end{array}$ & 10 & $\begin{array}{l}\text { K21, K23, K11, K12, } \\
\text { K19, K2, K3, K1, K8, } \\
\text { K17 }\end{array}$ \\
\hline
\end{tabular}




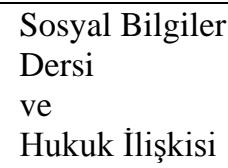

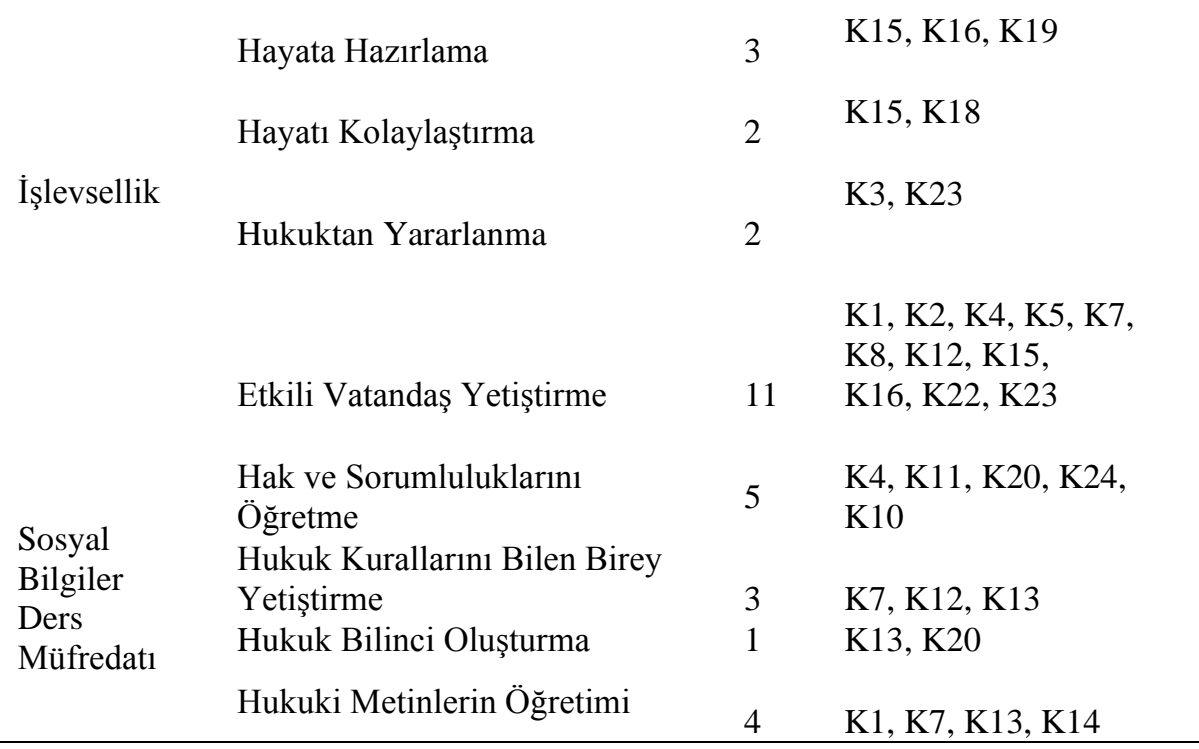

Tablo 11 incelendiğinde sosyal bilgiler öğretmen adaylarının sosyal bilgiler dersi ve hukuk arasındaki ilişkiye dair görüşlerinin "kapsam boyutu", "işlevsellik" ve "sosyal bilgiler ders müfredatı" olmak üzere üç alt tema altında toplandığı görülmektedir.

Katılımcıların “kapsam boyutu”ile ilgili temaya ait görüşlerinin bir kısmı aşağıda sunulmuştur:

K6:...Biz Sosyal Bilgiler öğretmeni olacağız. Bu dersin içinde birçok farklı bilimi öğretmeye çalışacağız öğrencilere. Düşünsenize coğrafi sinırlart anlatırken bu sintrların neye göre belirlendiğini, bu sınırların nasıl korunduğunu, sınırların korunması için diğer devletlerle yapılan anlaşmaları hukuk olmadan öğrenciye nasıl anlatacağım?...- "hukuk-coğrafya ilişkisi"

Katılımcıların “işlevsellik” ile ilgili temaya ait görüşlerinin bir kısmı aşağıda sunulmuştur:

K15:... İkisi de insanı hayata hazırlıyor. İnsanın yaşamı içerisinde, sosyal hayatını kolaylaştırıyor... Sosyal Bilgiler dersinde hukukun yer alması bireylerin hayata hazırlanmasın sağlıyor. Sosyal bir vatandaş oluyor birey... - "hayata hazırlama", "hayatı kolaylaştırma"

K23:... Sosyal bilimleri inceleyen disiplinleri inceleyen bir derstir. Hukuk da sosyal bir bilimdir. Sosyal bilgilerin amacı karşılaştıkları sorunlara karşı çözüm yolları üreten bireyler yetiştirmektedir. E bunu nasıl sağlayacak? Işste burada hukuk bu konuda Sosyal Bilgilere büyük yardım eder... - "sosyal bilgiler dersinde hukuktan yararlanma"

Tablo 12

Sosyal Bilgiler Öğretmen Adaylarının Sosyal Bilgiler Dersi Kapsamında Hukuk Konularını Öğretme Yeterliliklerine İlişkin Görüşleri

\begin{tabular}{|c|c|c|c|c|}
\hline Tema & Alt Tema & Kodlar & $\mathbf{f}$ & Katılımcı \\
\hline & & Sınav Odaklı Öğrenme & 7 & $\begin{array}{l}\mathrm{K} 1, \mathrm{~K} 3, \mathrm{~K} 4, \mathrm{~K} 9, \mathrm{~K} 17, \\
\mathrm{~K} 21, \mathrm{~K} 22\end{array}$ \\
\hline & & Not Kaygisı & 3 & $\mathrm{~K} 1, \mathrm{~K} 7, \mathrm{~K} 20$ \\
\hline & & $\begin{array}{l}\text { Öğretim Üyesinden Kaynaklı } \\
\text { Sorunlar }\end{array}$ & 13 & $\begin{array}{l}\mathrm{K} 1, \mathrm{~K} 2, \mathrm{~K} 4, \mathrm{~K} 8, \mathrm{~K} 9, \\
\mathrm{~K} 10, \mathrm{~K} 11, \mathrm{~K} 16, \mathrm{~K} 17, \\
\mathrm{~K} 19, \mathrm{~K} 20, \mathrm{~K} 23, \mathrm{~K} 24\end{array}$ \\
\hline & & Öğrenciden Kaynaklı Sorunlar & 4 & K1, K6, K14, K16 \\
\hline
\end{tabular}


Yeterli

Görmeme

Derslerin Teoride Kalması

K3, K7, K10, K12,

K13, K22, K23

Hukuki Terimleri Anlayamama

Aşırı Bilgi Yoğunluğu

Ezbere Dayalı Öğretim

Ders Saatinin Yetersiz Oluşu

Uygulamaya Dayalı Ders İşleme

Yeterli

Görme
Kavram Odaklı Ders

İşleme
$\mathrm{K} 8, \mathrm{~K} 13, \mathrm{~K} 20$

K14, K16

K17, K19, K21

3

K18, K19, K21

K15

Tablo 12 incelendiğinde öğretmen adaylarının sosyal bilgiler dersi kapsamında hukuk konularının öğretimine ilişkin görüşlerinin "yeterli görmeme" ve "yeterli görme" olmak üzere iki alt tema altında toplandı̆̆ görülmektedir.

Katılımcıların “yeterli görme” ile ilgili temaya ait görüşlerinin bir kısmı aşağıda sunulmuştur:

K5:...Hukuk konularını anlatmada kendimi yeterli görüyorum. Çünkü hocamız dersi uygulamaya dayalı işledi. Örneğin her hafta bir örnek üzerinden ilerlerdik ve o konuyla alakalı bir canlandırma yapardık. Bu sayede aklımızda çok iyi kaldı... Öğrencilere hukuk konularını nasıl ögreteceğimi de biliyorum... - "uygulamaya dayall ders işleme"

K15:...Biz dersleri hep kavram odakl işledik. Hocamız kavram ögrenmeye çok önem verirdi. Bu yüzden hukuki kavramları iyi ögrendik. Çocuklara da basit düzeyde anlatmayacak mıyı?? Ben bu konuda kendime güveniyorum. Kesinlikle anlatabilirim... - "kavram odaklı ders işleme" sunulmuştur:

Katılımcıların "yeterli görmeme" ile ilgili temaya ait görüşlerinin bir kısmı aşağıda

K1:...Etkin görmüyorum... Biz ögretim görürken not kaygısı olmadan içimizden gelerek görsek daha iyi bir şekilde ögrenebiliriz. Bizim hukuk alanında verilen derslerde hukuk fakültesinden gelen hocalar eğitimde ders veriyor. Hukuk fakültesinde anlatıldı ̆̆ gibi burada ögretmen adaylarına anlattı̆̆ında ögrenci çok fazla bunalıyor... - "not kaygısı", "ögretim üyesinden kaynaklı sorunlar"

K3:...Şuan bir sınıfa gireyim hukuk konularını öğretmeye çalışayım, öğretemem. Biz Temel Hukuk dersini zaten uzaktan eğitim ile aldik. Sadece sinavlarına girdik. Kesinlikle çok faydasız oldu. Uzaktan eğitimde sadece notlara baklyorsun ve insan kendi kendine ögrenemez yani... Bunlar çok yanlış uygulamalar... - "sinav odaklı öğrenme"

K8:... Biz dersi hep teorik işledik ki. Hadi teoriyi bir şekilde anlattım diyelim ya çocuk uygulama isterse? Biz teorikte çok iyiyiz ama pratiğe gelince işler çuvallyyor... Biz hukukla ilgili daha fazla eğitim almallyız... - "derslerin teoride kalması"

Tablo 13

Sosyal Bilgiler Öğretmen Adaylarının Almak İstedikleri Hukuk Öğrenimine Yönelik Görüşleri

\begin{tabular}{|c|c|c|c|c|}
\hline \multirow[t]{4}{*}{ Tema } & Alt Tema & Kodlar & $f$ & Katılımcı \\
\hline & & & & $\begin{array}{l}\text { K1, K2, K3, K4, K6, K7, } \\
\text { K8, K11, K12, K13, }\end{array}$ \\
\hline & Öğrenim Süreci & & 15 & $\begin{array}{l}\text { K14, K19, K20, K22, } \\
\text { K24 }\end{array}$ \\
\hline & Boyutu & Hukuk Öğretiminin & & \\
\hline
\end{tabular}




\begin{tabular}{|c|c|c|c|c|}
\hline & & Öğretilmesi & 4 & $\mathrm{~K} 2, \mathrm{~K} 10, \mathrm{~K} 16, \mathrm{~K} 18$ \\
\hline & & Materyal Desteği & 7 & $\begin{array}{l}\mathrm{K} 3, \mathrm{~K} 7, \mathrm{~K} 10, \mathrm{~K} 11, \mathrm{~K} 13, \\
\mathrm{~K} 22, \mathrm{~K} 23\end{array}$ \\
\hline & & & & $\begin{array}{l}\mathrm{K} 3, \mathrm{~K} 7, \mathrm{~K} 10, \mathrm{~K} 14, \mathrm{~K} 19, \\
\mathrm{~K} 21, \mathrm{~K} 23\end{array}$ \\
\hline & & Mahkeme Ziyareti & 7 & \\
\hline & & Duruşma İzleme & 2 & $\mathrm{~K} 3, \mathrm{~K} 4$ \\
\hline & Sosyal Yașam & $\begin{array}{l}\text { Hukuk Uzmanıyla Röportaj } \\
\text { Yapma }\end{array}$ & 2 & $\mathrm{~K} 12, \mathrm{~K} 14$ \\
\hline $\begin{array}{l}\text { İdeal Hukuk } \\
\text { Öğrenimi }\end{array}$ & $\begin{array}{l}\text { İle İlişkilendirme } \\
\text { Boyutu }\end{array}$ & Güncel Hayata Adapte Etme & 10 & $\begin{array}{l}\text { K5, K7, K9, K14, K15, } \\
\text { K16, K19, K20, K22, } \\
\text { K23 }\end{array}$ \\
\hline & & Yalın Ders İçeriği & 3 & $\mathrm{~K} 1, \mathrm{~K} 22, \mathrm{~K} 14$ \\
\hline & Ders İçeriği & Ortak Ders Müfredatı & 1 & $\mathrm{~K} 2$ \\
\hline & Boyutu & & & $\mathrm{K} 7, \mathrm{~K} 18, \mathrm{~K} 24$ \\
\hline & & Ders Saatinin Arttırılması & 3 & \\
\hline & & $\begin{array}{l}\text { Hukuk Uzmanından Hukuk } \\
\text { Öğrenimi }\end{array}$ & 5 & $\mathrm{~K} 4, \mathrm{~K} 11, \mathrm{~K} 17, \mathrm{~K} 19, \mathrm{~K} 21$ \\
\hline & & $\begin{array}{l}\text { Pedagojik Formasyon Almış } \\
\text { Olma }\end{array}$ & 1 & $\mathrm{~K} 3, \mathrm{~K} 8, \mathrm{~K} 10$ \\
\hline & Öğretim Üyesi Boyutu & $\begin{array}{l}\text { Derse Kısmi Zamanlı } \\
\text { Hukukçu Dahil Etme }\end{array}$ & 1 & K12 \\
\hline & $\begin{array}{l}\text { Öğrenimin } \\
\text { Değerlendirilmesi }\end{array}$ & $\begin{array}{l}\text { Projeye Dayalı } \\
\text { Değerlendirme }\end{array}$ & 2 & K6, K12 \\
\hline & Boyutu & Süreç Odaklı Değerlendirme & 2 & $\mathrm{~K} 1, \mathrm{~K} 17$ \\
\hline
\end{tabular}

Tablo 13 incelendiğinde sosyal bilgiler öğretmen adaylarının almak istedikleri hukuk öğrenimine ilişkin görüşlerin "öğrenim süreci boyutu”, "sosyal yaşam ile ilişkilendirme boyutu”, "ders içeriği boyutu", "öğretim üyesi boyutu" ve "öğrenimin değerlendirilmesi boyutu" olmak üzere beş alt tema altında toplandığı görülmektedir. sunulmuştur:

Katılımcıların “öğrenim süreci boyutu” ile ilgili temaya ait görüşlerinin bir kısmı aşağıda

K16:...Bana direk şunu ögretsinler, çocuklara hukukla alakalı konuları nasıl öğreteceğimi anlatsınlar. Ben hukuku ögrenciye en kolay nasıl anlatabilirim onu öğrenmek istiyorum. Çünkü sadece hukuk konularını bilmek değil benim için aynı zamanda nasıl öğreteceğimi de bilmek önemli...- "hukuk öğretiminin ögretilmesi"

K22:...Dersin hocası bizi de derse dahil etse çok daha güzel ögrenirdik. Mesela hukukla ilgili bir hikaye getirebilirdi bize ya da dava örnekleri getirebilirdi... Örnekler sunsaydı çok daha kalıcı olabilirdi bizim için ...- "uygulamaya dayalı ögrenim", "materyal desteği 
K7:...Bence uygulamalı olmalı...Şuan ki çıkan yasalarla, TBMM ile ilgili yaşadı̆̆ımız şeyleri ögrensek çok daha fazla kalıcı olur bizim için...Hepimiz gidiyoruz sonuçta evde haberleri izliyoruz. Yeni kanunlar çıkıyor. Mesela şuan olağanüstü hal var. Daha önce sadece teori olarak biliyorduk... Yaşadı̆̆ımız her şey daha kalıcı... - "uygulamaya dayalı öğrenim”"

Katılımcıların "öğrenimin değerlendirmesi boyutu” ile ilgili temaya ait görüşlerinin bir kısmı aşağıda sunulmuştur:

K12:...Bence biz sınav odaklı çalıştı̆̆ımız için tam öğrenemiyoruz. Artık üniversiteye gelmişiz ama hala sınava giriyoruz. Bize hukuk ile ilgili bir proje verseler mesela, dönem sonuna kadar onu yapsak. Sinav yerine o geçse. Tabi ki kapsamlı bir şey yapacağız. Dönem sonunda da onu gelip sunsak sinıfta. Böylece hem herkes birbirinin projesini ögrenir hem de daha fazla kalıcı olur bence.... "projeye dayall değerlendirme"

K1:...Öğretmen adaylarının en büyük derdi sınıfta kalmamak ve sinavlar. Böyle olunca da ezberliyoruz. Hocaların bunu sürece yayması lazım. Sınavdan ziyade ögrenci her derse hazırlıkl gelmiş mi? dönem boyunca derste söz almış mı? Derse katılmış mı? Bunlara bakması lazım bence... - "süreç odakl değerlendirme"

\section{Sonuç, Tartışma ve Öneriler}

Sosyal bilgiler öğretmen adaylarının hukuk okuryazarlık düzeylerinin belirlenmesini amaçlayan araştırma, nicel ve nitel yöntemlerin eş zamanlı uygulanmasıyla oluşan yakınsayan paralel desen modeli ile oluşturulmuştur. Bu bölümde nicel ve nitel analiz bulgularından elde edilen sonuçlar bütünleştirilerek birlikte yorumlanmıştır.

Araştırmada öncelikle sosyal bilgiler öğretmen adaylarının hukuk okuryazarlık bilgi düzeyleri incelenmiştir. Araştırmanın nicel verilerinden elde edilen sonuca göre, öğretmen adaylarının hukuk okuryazarlık bilgi düzeylerinin çoğunlukla orta düzeyde olduğu görülmüştür. Nitel verilerinden elde edilen sonuçlara göre ise öğretmen adaylarının birçoğunun sosyal bilgiler dersi kapsamında hukuk konularının öğretiminde kendilerini yetersiz gördükleri ortaya çıkmıştır. Bu sonuçlardan yola çıkarak, öğretmen adaylarının hukuk okuryazarlık bilgi düzeylerinin yüksek düzeyde olmadığından dolayı kendilerini yeterli görmedikleri sonucu çıkarılabilir. Pereria (1988) çalışmasında, sosyal bilgiler öğretmenlerinin hukuk konularının öğretimini etkin bir şekilde gerçekleștirebilmeleri için hukuka yönelik yüksek düzeyde bilgi sahibi olmaları gerektiğini vurgulamıştır. Bu bağlamda geleceğin etkin vatandaşlarını yetiştirmede önemli bir yere sahip olan sosyal bilgiler öğretmen adaylarının orta düzeyde hukuk okuryazarlık bilgisine sahip olması ve hukuk konularının öğretiminde kendilerini yeterli görmemeleri düşündürücüdür. Militello ve Schimmel (2012) ve Wagner (2007) gerçekleştirdikleri araştırmalarda, öğretmenlerin ve yöneticilerin hukuk okuryazarlık bilgi düzeylerinin düşük olmasından dolayı okulda karşılaştıkları problemlere çözüm üretme konusunda kendilerini yetersiz hissettikleri sonucuna ulaşmışlardır. Oğuz (2013) gerçekleştirdiği araştırmasında, ortaokul öğrencilerinin de hukuk okuryazarlık bilgi düzeyinin çoğunlukla orta düzeyde yer aldığı sonucuna ulaşmıştır. Bu bağlamda hukuk okuryazarlık bilgi düzeyinin, sosyal bilgiler dersi kapsamında hukuk konularının etkili bir şekilde öğretimi ve hukuksal problemlerin çözümünde önemli bir etken olduğu söylenebilir. Sosyal bilgiler öğretmen adaylarının hukuk okuryazarlık bilgi düzeylerinin incelenmesinden sonra, öğretmen adaylarının bilgi düzeylerinin cinsiyet ve hukuki süreç yaşamış olma değişkenlerine göre anlamlı bir fark gösterip göstermediği incelenmiştir. Cinsiyet değişkenine yönelik yapılan analiz sonucunda, hukuk okuryazarlık bilgi düzeyinin erkek öğretmen adaylarının lehine anlamlı bir fark gösterdiği ortaya çıkmıştır. Sobhan (1992) ve Zuckerman ve Greenberg (2004) gerçekleştirdikleri araştırmada, hukuk okuryazarlık bilgi düzeyi ve cinsiyet değişkeni arasında benzer bir sonuca ulaşmışlardır. Ayrıca Hindistan ve Etiyopya'da da hukuk okuryazarlık bilgi düzeylerinin düşük olmasından dolayı kadınlara, hukuk okuryazarlık bilgi düzeylerini yükseltmeye yönelik projeler gerçekleştirilmektedir (Addis Ababa Üniversitesi, t.y.; Bhatnagar, Dewan, Torres ve Kanung, 2003). Bu sonuçlardan yola çıkarak, kadınların hukuk okuryazarlık bilgi düzeylerinin erkeklere nazaran düşük düzeyde olması, ülkelerde var olan ataerkil yapıdan kaynaklı olabilir. Sosyal bilgiler öğretmen adaylarının hukuk okuryazarlık bilgi düzeylerinin hukuki süreç yaşamış olma değişkenine göre anlamlı bir fark gösterip göstermediği incelendiğinde, 
hukuki süreç yaşamış olan öğretmen adaylarının lehine anlamlı bir fark bulunmuştur. Araştırmanın nitel verilerinden elde edilen sonuçlara göre ise öğretmen adaylarının almak istedikleri hukuk eğitimine yönelik "sosyal yaşam ile ilişkilendirme boyutu" temasının olduğu göze çarpmaktadır. Jeffrey ve Chant (2000) gerçekleştirdikleri araştırmada, öğrencilerin hukuku özümseyebilmeleri için, hukuk konularının sosyal hayatları içerisinde var olması gerektiğini vurgulamışlardır. Bu sonuçlardan yola çıkarak, sosyalbilgiler öğretmen adaylarının hukuk okuryazarlık bilgi düzeylerinin, sosyal yaşamları içerisinde hukukun var olma düzeyinden etkilendiği söylenebilir.

Araştırmanın bir diğer alt problemi ise sosyal bilgiler öğretmen adaylarının hukuk okuryazarlık ölçeğine göre düzeylerinin belirlenmesidir. Yapılan analiz sonucunda sosyal bilgiler öğretmen adaylarının hukuk okuryazarlık ölçeğine göre düzeylerinin çoğunlukla orta düzeyde olduğu görülmüştür. Leming (1995) sosyal bilgiler öğretmen adaylarının etkin vatandaş yetiştirmede etkili olabilmeleri için yüksek düzeyde hukuki tutum ve davranışlara sahip olması gerektiğini vurgulamıştır. Bu bağlamda sosyal bilgiler öğretmen adaylarının hukuki tutum ve davranışların yüksek düzeyde olması beklenmektedir. Sosyal bilgiler öğretmen adaylarının hukuk okuryazarlık ölçeğine göre düzeylerinin cinsiyet ve hukuki süreç yaşamış olma değişkenlerine göre anlamlı bir fark gösterip göstermediği incelendiğinde; cinsiyet değişkenine bağlı olarak anlamlı bir fark bulanamazken, hukuki süreç yaşamış olma değişkenine göre, hukuki süreç yaşamış olan öğretmen adaylarının lehine anlamlı bir farkl1l1k bulunmuştur. Hoge (2002) günlük hayatta hukuki bir durumla karşılaşmanın, hukuki tutum ve davranış üzerinde etkili olduğunu belirtmektedir. Bu sonuçlardan yola çıkarak, hukuki bir süreç yaşamış olmanın, hukuki tutum ve davranışları etkilediği söylenebilir.

Son olarak sosyal bilgiler öğretmen adaylarının nasıl bir hukuk öğrenimi almak istediklerine dair düşünceleri incelenmiştir. Araştırmanın nitel sonuçlarına göre öğretmen adayları; uygulamaya dayal1, materyaller ile desteklenmiş ve sosyal hayat ile ilişkilendirilmiş bir hukuk öğrenimi almak istemektedir. Fischer ve Schimmel (1974) hukuk konularının öğretiminde hukukla ilgili kitaplardan, filmlerden ve hukuki uzmanlardan yararlanılması gerektiğini, derslerin gerçek olaylardan yola çıkarak anlatılmasını, dersin sadece sınıf içerisinde değil kütüphane ve hukuki mercileri ziyaretler ile yapılması gerektiğini, gazete ve dergilerde yer alan vaka incelemeleri ile ders etkinliğinin arttırılmasını ve derslerin yaratıcı drama tekniği gibi öğrenci odaklı tekniklerle işlenmesi gerektiğini vurgulamışlardır. Nessel (2002) gerçekleştirdiği araştırmasında, hukuk konularının öğretiminde uyguladığı genç mahkemeler etkinliğinin öğrencilerdeki hukuka yönelik bilgi, tutum ve davranış1 olumlu yönde etkilediğini ortaya çıkarmıştır. Hanson (2002) ise hukuk konularının öğretiminde simülasyon kullanımının, öğrencilerdeki hukuka yönelik bilgi, tutum ve davranışları olumlu yönde etkilediğini gözlemlemiştir. Yazıcı ve Erdilmen (2015) ise sosyal bilgiler kapsamında hukuk konularının öğretiminde güncel yaşamda var olan örneklerden yararlanılması gerektiğini ve öğretimin sınıf içi ve sınıf dışı etkinliklerle desteklenmesi gerektiğini vurgulamışlardır. Bu sonuçlardan yola çıkarak, sosyal bilgiler öğretmen adaylarına verilen hukuk öğretiminin uygulamaya, sosyal yaşama ve materyallere dayalı olarak gerçekleştirilmesinin, öğretmen adaylarındaki hukuk okuryazarlık bilgi, tutum ve davranışları olumlu yönde etkileyeceği söylenebilir.

Araştırmanın sonuçları bütüncül bir yaklaşım ile ele alındığında, sosyal bilgiler öğretmen adaylarının geleceğin etkin vatandaşlarını yetiştirmeleri için gerekli olan hukuk okuryazarlık bilgi ve davranış düzeylerinin yeterli düzeyde olmadığı ve birçoğunun kendini sosyal bilgiler dersi kapsamındaki hukuk konularının öğretiminde yetersiz gördüğü ortaya çıkmıştır. İlgili literatür ve elde edilen sonuçlar ışığında aşağıdaki öneriler sunulmuştur.

- İlgili literatür ve araştırma sonuçlarından yola çıkarak, araştırmacı tarafından Hukuk Okuryazarlığı Öğretim Modeli önerisi geliştirilmiştir. Önerilen bu model Şekil 1'de sunulmuştur. 




Şekil 1. Hukuk Okuryazarlığı Öğretim Modeli Önerisi.

- Alan uzmanları tarafindan, sosyal bilgiler öğretmen adaylarının hukuk okuryazarlık düzeylerini geliştirmek adına TÜBİTAK ve Avrupa Birliği 7. Çerçeve Programı destekli projeler geliştirilebilir.

- Hukuk okuryazarlıklarının öğretimine ilişkin sosyal bilgiler öğretmen adaylarına deneysel çalışmalar gerçekleştirilebilir ve bu araştırmaların etkililiği değerlendirilebilir.

\section{Yazarların Katkı Oranı}

Bu makaleye birinci yazarın \%50, ikinci yazarın \%50 oranında katkısı vardır.

\section{Çıkar Çatışması}

Çıkar çatışması teşkil edebilecek bir durum yoktur.

\section{Kaynaklar}

Addis Ababa University. (n.d.). Legal literacy, rights advice and information for people. Retrieved from $\quad$ http://www.aau.edu.et/humanrights/index.php/project/legal-literacy-rights-adviceinformatio in 12.02.2017.

Aydın, O. G. (2015). Gelecekten geleneğe Türkiye'de hukuk eğitimi. Türkiye Adalet Akademisi Dergisi, 6 (21), 621-656.

Bakır, K. (2014). Demokratik eğitim: Jonh Dewey’in eğitim felsefesi üzerine. Ankara: Pegem Akademi. 
Bell, D. and Pether, P. (1998). Rewriting skills training in law schools-legal literacy revisited. Legal Education Review, 9 (2), 113-122. Retrieved from http://www.austlii.edu.au/au/journals/LegEdRev/1998/6.html in 14.02.2017.

Bhatnagar, D., Dewan, A., Torres, M. and Kanung, P. (2003). Kashi rural legal literacy project. Indian Institute of Management and Magüi Moreno Torres and Parameeta Kanungo at the World Bank. Retrieved from http://siteresources.worldbank.org/INTEMPOWERMENT/Resources/14873 Kashi-web.pdf in 18.03.2017.

Bilder, M. S. (1999). The lost lawyers: early american legal literates and transatlantic legal culture. Yale Journal of Law \& the Humanities, 11 (1), 47-72. Retrieved from http://digitalcommons.law.yale.edu/cgi/viewcontent.cgi?article=1207\& context=yjlh in 14.02.2017.

Braye, S. and Preston Shoot, M. (2005). Law in social work education: reviewing the evidence on teaching, learning and assessment. Social Work Education, 24 (5), 547-563. doi:10.1080/0261547050013283

Büyüköztürk, Ş. (2016). Bilimsel araştırma yöntemleri. Ankara: Pegem Akademi Yayıncılık.

Can, A. (2014). SPSS ile bilimsel araştırma sürecinde nicel veri analizi. Ankara: Pegem Akademi Yayınc1lk.

Creswell, J. W. ve Plano Clark, V. L. (2015). Karma yöntem araştırmaları tasarımı ve yürütülmesi (2. baskı). (Y. Dede ve S. B. Demir, Çev. Ed.). Ankara: Anı Yayıncılık.

Doran, I. and Hoffman, A. (2005). Time to law: legal literacy ang gerontological education. Educational Gerontology, 31 (8), 627-642. doi:10.1080/036012705 91003373

Field, A. (2009). Discovering statistics using SPSS (3nd ed.) London: SAGE Publications.

Fischer, L. and Schimmel, D. (1974, November). Legal Literacy and Teacher Education: A Case Approach Based on the Rights of Teachers and Students. Paper presented at the Annual Convention of the National Organization for Legal Problems in Education, Florida.

Fultz, L. J. (2015). Igniting the conversation: embracing legal literacy as the hearth of the profession. Law Library Journal, 107 (3), 421-439. Retrieved from https://ssrn.com/abstract=2773811 in 01.11 .2016

Hanson, R. L. (2001). The case for law-related education. Educational Leadership. 59 (4), 61-64. Retrieved from http://www.ascd.org/publications/educational_ leadership/dec01/vol59/num04/The_Case_for_Law-Related_Education.aspx in 25.06.2016

Hasan, F. R. (1994). Limits and possibilities of law and legal literacy / experience of Bangladesh women. Economic and Political Weekly, 29 (44), 69-76. Retrieved from http://www.epw.in/journal/1994/44/review-womens-studies-review-issues in 12.05.2016

Hoge, J. D. (2002). Character education, citizenship education and the social studies. The Social Studies, 93 (3), 103-108. doi:10.1080/00377990209599891

Korpiola, M. (2015). Call for papers: learning law by doing: exploring legal literacy in premodern sociesties. European Society for Comparative Legal History. 1 (1), 1-8. Retrieved from http://esclh.blogspot.com.tr/2015/10/call-for-papers-learning-law-by-doing.html in 30.05.2016 
Leming, R. (1995). Essentials of law-related education. Bloomington: ERIC Clearinghouse for Social Studies/Social Science Education.

Milli Eğitim Bakanlığı (2009). İlköğretim sosyal bilgiler dersi öğretim programı ve kılavuzu (4,5,6,7. Sinıflar). Erişim adresi https://ttkb.meb.gov.tr/www/ogretim-programlari /icerik/72 12.01.2016 tarihinde erişilmiştir.

Merey, Z., Karatekin, K. ve Kuş, Z. (2012). İlköğretimde vatandaşlık eğitimi: karşılaştırmalı kuramsal bir çalışma. Gazi Üniversitesi Gazi Eğitim Fakültesi Dergisi, 32 (3), 795-821.

Miles, M. B. and Huberman, A. M. (1994). Qualitative data analysis (2nd ed.). California: SAGE Publications.

Militello, M., and Schimmel D. (2012). Toward universal legal literacy in american schools. Action in Teacher Education, 30 (2), 98-106, doi:10.1080/01626620.2008.10463496 .

Naylor, D. T. (1976). Values: law-related edocation and the elementary school teacher. Washington: NEA Publications.

National Council for the Social Studies. (1994). Expectations of excellence: curriculum standards for the social studies. Washington, D.C.: National Council for the Social Studies.

Nessel, P. A. (2002). Youth courts in law-related education. Bloomington: ERIC Clearinghouse for Social Studies/Social Science, Education.

Oğuz, S. (2013). Ortaokul öğrencilerinin sosyal bilgiler eğitimi çerçevesinde hukuk okuryazarlık düzeylerinin belirlenmesi. Doktora Tezi, Gazi Üniversitesi, Eğitim Bilimleri Enstitüsü, Ankara.

Öztürk C. (2012). Sosyal bilgiler: toplumsal yaşama disiplinlerarası bir bakış. C. Öztürk (Ed.), Sosyal bilgiler ögretimi demokratik vatandaşlık eğitimi içinde (2. baskl). (ss. 1-31). Ankara: Pegem Akademi Yayınc1lı.

Patton, M. Q. (2014). Nitel araştırma ve değerlendirme yöntemleri. (M. Bütün ve S. B. Demir, Çev. Ed.). Ankara: Pegem Akademi Yayıncılık.

Pereira, C. (1988). Law-related education in elementary and secondary schools. Bloomington: ERIC Clearinghouse for Social Studies/Social Science Education.

Robson, C. (2015). Bilimsel araştırma yöntemleri gerçek dünya araştırması. (Ş. Çınkır ve N. Demirkasımoğlu, Çev. Ed.). Ankara: Anı Yayıncılık.

Skopska, G. (2001). Law and democracy. N.J. Smelser and P.B. Baltes (Ed.), International of the social and behavioral sciences in (pp. 8439-8443). United Kingdom: Pergamon.

Snook, B., Luther, K., Eastwood, J.,Collins, R. and Evans, S. (2014). Advancing legal literacy: The effect of listenability on the comprehension of interrogation rights, Legal and Criminological Psychology, 21, 174-188. doi:10.1111/lcrp.12053

Sobhan, S. (1992). Legal literacy and community development in Bangladesh: Bangladesh Rural Advancement Committee. M. Schuler and S. Kadirgamar-Rajasingham (Eds.). In: Legal literacy: A tool for women's empowerment, (pp. 229-245). New York, United Nations Development Found for Women. 
Steininger, K. and Rückel, D. (2013, 27th February-1st March). Legal literacy and users' awareness of privacy, data protection and copyright legislation in the web 2.0 era, Paper submitted 11th International Conference on Wirtschaftsinformatik, Leipzig.

Şeker, H. ve Gençdoğan, B. (2014). Psikolojide ve eğitimde ölçme aracı geliştirme (2. baskı). Ankara: Nobel Akademik Yayınc1lık.

Wagner, P. H. (2007, November). An evaluation of the legal literacy of educators and the implications for teacher preparation programs. A paper presented at the Education Law Association 53rd Annual Conference, California.

Yazıcı, K. ve Erdilmen, Ş. (2015). Sosyal bilgiler öğretiminde hukuk. R. Turan ve K. Ulusoy (Ed). Sosyal bilgilerin temelleri içinde (4. baskl). (ss. 257-278). Ankara: Pegem Akademi Yayıncilik.

Yıldırım, A. ve Şimşek, H. (2008). Sosyal bilimlerde nitel araştırma yöntemleri (6. baskı) Ankara: Seçkin Yayıncılık.

Zariski, A. (2014). Legal literacy: an introduction to legal studies. Edmonton: AU Press.

Zuckerman, E. and Greenberg, M. (2004) The gender dimensions of postconflict reconstruction: $A n$ analytical framework for policymakers. Gender \& Development, 12 (3), 70-82. doi:10.1080/13552070412331332330 


\section{Extended Summary}

\section{Introduction}

In states that have embraced democracy, the law cannot be considered separate from the state's regime. Because the protection of individuals or social groups in the society, the struggle for the fulfillment of the acquired rights, and their participation in the political decision-making processes can only be possible with the implementation of legal rules (Skopska, 2001). In this context, every state governed by a democratic regime needs effective individuals who ensure the continuation of the law in a certain order as much as it needs the existence of law (Aydin, 2015). Because democracy is a form of life as well as a form of political government (Copper, 2014). Legal literacy is a great necessity for societies where individuals are aware of their rights and personal freedoms, can live in dignity and freedom, away from social fears, and where individual life is experienced in the widest scope and dimension (Braye \& Preston Shoot, 2005; Upadhyay, 2005). In order for a legal society to be meaningful, individuals in society must be legal literate. In other words, legal literacy includes all individuals in society (Bell \& Pether, 1998). The most important duty of the state at this point is to raise individuals who are aware of their rights and responsibilities and to provide the conditions of the environment in which these individuals will grow (Çuhadar \& Doğanay, 2014). For this reason, since the early 1970s, legal issues have been added to the Social Studies course curriculum of primary and secondary school students (Naylor, 1976; Öztürk, 2009). The added subjects are generally determined to be suitable for the students' levels such as basic legal concepts, crime and penal code, constitution, civil law, and human rights declaration (Merey, Karatekin, \& Kuş, 2012). These subjects included in the Social Studies course focus not on specialization in legal studies, but on making sense of the relationship between democracy and law as a citizen. The teaching of legal subjects in the Social Studies course enables students to improve their legal knowledge, skills and attitudes as well as the legal roles required for effective citizenship (Leming, 1995). In this context, legal studies are used as a tool to teach students the social structure and social values they live in (Naylor, 1976). For Social Studies teacher candidates, who will train active citizens of the future, to perform an effective education, it is of great importance that they are good legal literate. In this context, it was aimed to determine the legal literacy levels of Social Studies teacher candidates who will teach law subjects within the scope of Social Studies course and to examine their thoughts on law and law education within the scope of Social Studies course.

\section{Method}

The convergent parallel pattern model, which is one of the mixed research methods, was used in the study. Studies created with mixed-method are the result of combining quantitative and qualitative methods to determine the breadth and depth of the research (Robson, 2015). The sample of the study consists of 610 3rd grade teacher candidates studying in the Department of Social Studies Education in the 2016-2017 Education Year, which were selected by disproportionate cluster sampling. The study group in the qualitative dimension of the study was determined by purposeful random sampling. In this context, a total of 24 Social Studies teacher candidates, one female and one male from each of the 12 universities included in the study, were determined as participants. Legal Literacy Knowledge Test and Legal Literacy Scale developed by the researcher to collect quantitative data in the research; A semi-structured interview form developed by the researcher was used to collect qualitative data. The legal literacy knowledge test consisted of 26 items with four premises and KR-20 reliability coefficient was calculated as 0.74 . The legal literacy scale, which was developed to measure the legal literacy levels of teacher candidates, is in a 5-point Likert type and consists of 29 items. The total Cronbach's alpha reliability coefficient of the scale was found to be ,81. SPSS.21 analysis program was used to analyze the quantitative data. All analyses in the study accepted the level of significance as .05. Qualitative data were analyzed with content analysis. 


\section{Discussion and Conclusion}

In the research, firstly, the legal literacy knowledge levels of Social Studies teacher candidates were examined. According to the result obtained from the quantitative data of the research, it was seen that the legal literacy knowledge level of the teacher candidates was mostly at medium level. According to the results obtained from the qualitative data, it was revealed that most of the teacher candidates considered themselves insufficient in teaching legal subjects within the scope of the Social Studies course. Based on these results, it can be concluded that teacher candidates do not consider themselves competent because their knowledge of legal literacy is not high. Another sub-problem of the study is the determination of the levels of Social Studies teacher candidates according to the legal literacy scale. As a result of the analysis, it was seen that the levels of Social Studies teacher candidates according to the legal literacy scale were mostly at medium level. It is expected that the legal attitudes and behaviors of Social Studies teacher candidates will be at a high level. When the social studies teacher candidates' levels according to the legal literacy scale were examined, it was examined whether there was a significant difference according to the variables of gender and having a legal process; While no significant difference could be found depending on the gender variable, a significant difference was found in favor of pre-service teachers who had a legal process, according to the variable of having a legal process. Based on these results, it can be said that having a legal process affects legal attitudes and behaviors. Finally, the opinions of Social Studies teacher candidates about what kind of law education they want to study were examined. According to the qualitative results of the research, teacher candidates; wants to have a law education that is based on practice, supported by materials, and associated with social life. In light of these results, the researchers have developed a legal literacy teaching model proposal. 